JACEK SÓJKA

\title{
POJĘCIE KULTURY W TEORII ZARZĄDZANIA
}

\begin{abstract}
Sójka Jacek, Pojęcie kultury w teorii zarządzania [The notion of culture in management theory] edited by W. Banach - „Człowiek i Społeczeństwo”, vol. XXXVIII, Poznań 2014, pp. 109-120, Adam Mickiewicz University Press. ISBN 978-83-232-2791-5. ISSN 0239-3271.

The aim of this article is to explore the way the notion of culture has been presented in management theories. In some instances, the concept was absent; but a closer inspection can reveal that culture was an issue or a challenge for managers - as it was the case with taylorism, which actually tried to overcome the cultural differentiation of the workforce. Today, intercultural management and the concept of organizational culture are a crucial part of management theory and education. But the abundance of books and articles on the impact of culture on the economy poses yet another challenge for the students of culture. Is this phenomenon understood correctly, and does intercultural management do justice to the nature of culture and intercultural relations? Perhaps the focus on culture has been blown out of proportion, and perhaps it is meant to hide a purely technocratic attitude toward the workforce? Nevertheless, it would be hard to understand globalization without taking into account the transcultural phenomen of today's management.
\end{abstract}

Jacek Sójka, Uniwersytet im. Adama Mickiewicza w Poznaniu, Wydział Nauk Społecznych, Instytut Kulturoznawstwa, Zakład Etyki Gospodarczej, ul. Szamarzewskiego 89a, 60-568 Poznań, Poland.

\section{WSTĘP}

Celem tego artykułu jest ukazanie obecności problematyki kultury w naukach o zarządzaniu. O takiej obecności możemy mówić nie tylko wówczas, gdy pojawia się pojęcie kultury i odgrywa ważną rolę w konstruowaniu danej koncepcji, ale także wtedy, gdy pojęcie to nie jest obecne, niemniej mówi się o zagadnieniach, które kultury dotyczą, lub o procesach, w których decydującą rolę odgrywa to, co dana grupa ludzi myśli i w jaki sposób postrzega rzeczywistość. Oczywiście, w tym tekście możliwe będzie tylko ogólne naszkicowanie tytułowego problemu, bowiem dokładne jego przedstawienie wymagałoby pracy o wiele bardziej obszernej. 


\section{ROZUMIENIE KULTURY}

Kultura powinna być obecna w teorii zarządzania, bowiem problematyka ta jest, jak się wydaje, zasadnicza dla gospodarki, w przeszłości i obecnie. Można mówić o istnieniu wzorów kultury gospodarczej, a zatem takich wartości, norm i przekonań, które mają decydujące znaczenie dla funkcjonowania całej gospodarki, przedsiębiorstw oraz jednostek zaangażowanych w procesy gospodarcze na pełnej długości tzw. łańcucha dostaw. Jednak to, co nazywamy kulturą gospodarczą, jest tylko wyodrębnioną dla celów analitycznych częścią szerszej kultury, która - by tak rzec - nie skupia się wyłącznie na gospodarce, a nawet może od niej uciekać w sferę bardziej pierwotną i bardziej faworyzowaną, wykraczającą poza byt doczesny. Niemniej religijny charakter kultury i akcent położony na transcendencję nie jest obojętny dla ukształtowania się systemów gospodarczych w danym czasie. Należy powiedzieć więcej: wszelkie formy religijności zawsze miały widoczny wpływ na formy gospodarowania. Nie było bodaj religii, która nie regulowałaby w jakiś sposób działalności gospodarczej.

Średniowiecze i religijna wizja świata ujmowały gospodarkę jako grę o sumie zerowej. Bogactwo jednych oznaczało ubóstwo drugich, zdobywanie pieniędzy pociągało za sobą eksploatację innych ludzi. Tak czy owak majątek łączył się z niesprawiedliwością. Kalwin odrzuca jednak sposób myślenia św. Hieronima i św. Augustyna i w swoich komentarzach do Pisma Świętego twierdzi, że występowanie przeciwko bogactwu byłoby bluźnierstwem. "Skąd miałoby pochodzić bogactwo, jeżeli nie od Boga?" (Komentarz do Księgi Wyjścia). A w innym miejscu: „Niedola jest znakiem nieobecności Boga; powodzenie w interesach - Jego obecności" (Komentarz do Księgi Rodzaju) ${ }^{1}$. Wpływu reformacji na kształtowanie się nowożytnej gospodarki nie trzeba tutaj szerzej tłumaczyć. Są to kwestie znane i oczywiste (aczkolwiek dyskutowane do dzisiaj). Warto jednak podkreślić, iż wpływ przemian doktrynalnych $\mathrm{w}$ Kościele na gospodarkę jest klasycznym przykładem roli kultury w procesach gospodarczych.

Czym jest jednak kultura? Przyjmijmy, że są to podzielane przez daną wspólnotę (większą lub mniejszą) pewne wartości, normy i przekonania opisowe. Fakt, iż są one „podzielane”, jest efektem socjalizacji jednostek, przekazu międzypokoleniowego oraz „bieżącej” komunikacji utrwalającej pewne treści. Kulturę dziedziczymy zatem, lecz nie w sensie genetycznym, biologicznym. W efekcie umożliwia ona komunikację i - paradoksalnie -

${ }^{1}$ J. Calvin, Commentary on Exodus, 11:2; Commentary on Genesis 39:1, cyt. za: B.M. Friedman, The Moral Consequences of Economic Growth, Alfred A. Knopf, New York 2005, s. 43. 
sama istnieje dzięki komunikacji. Warunkuje też postrzeganie i interpretowanie świata, przy czym nie da się oddzielić postrzegania od interpretacji. W uproszczeniu, może być rozumiana jako wspólnotowa wiedza, co pozwala między innymi na odróżnienie tej sfery myślowej od jej wytworów, np. konwencji artystycznej od samego dzieła sztuki, oraz od zachowań ludzkich przez nią regulowanych (wzorów zachowań od samych zachowań)2

W Europie, chociaż nie tylko, istnieje skłonność to utożsamiania kultury $\mathrm{z}$ kulturą narodową. W ujęciu modelowym kultura jest jednolitym obszarem przekonaniowym, a jednocześnie treścią pewnej hipotezy dotyczącej tego, co łączy określoną grupę ludzi i co pozwala wytłumaczyć zachowania członków tej grupy jako reprezentantów swojej kultury. Kultura narodowa jest taką hipotezą przypisującą narodowi $\mathrm{w}$ trybie idealizacyjnym konkretny zestaw wartości, norm i przekonań. Mówimy więc o kulturze francuskiej czy włoskiej. Gdy jednak zainteresuje nas bliżej Francja lub Włochy, spostrzegamy, że kultury rozpadają się na subkultury, podlegają wpływom innych kultur, tworzą formy hybrydyczne, a zatem rzeczywistość nie daje się szufladkować według kryteriów narodowych. Kultura łączy więc ludzi, ale też pozwala im samym odkrywać różnice. Wspólny język nie musi oznaczać takiej samej interpretacji świata. Arjun Appadurai mówił w tym kontekście o kulturze jako tworzącej „luźne archiwum różnic” (archive of differences) ${ }^{3}$. Dzięki kulturze rozpoznajemy się nawzajem, ale jednocześnie odkrywamy, że się różnimy.

Można porównać kulturę do programu, który tworzy nasz umysł, jak chciał tego Geert Hofstede (software of the mind) ${ }^{4}$. Wówczas mózg przypominałby hardware, co odpowiadałoby tradycyjnemu dualizmowi i jednocześnie problemowi mind - body. Należy jednak pamiętać o umowności tego porównania. Kultura powoduje rodzaj zaprogramowania umysłu, jednakże nie istnieje jeden centralny programista i jeden identyczny program dla wszystkich. (W podobnie „mechaniczny” sposób rozumie się czasami kulturę narodową). O tym, za co krytykowano Hofstedego, będzie jeszcze tutaj mowa.

2 Pewne uproszczenia są niezbędne, bowiem o samym pojęciu kultury można bardzo długo rozprawiać, jednak na jakieś jej rozumienie trzeba się zdecydować, aby móc z niego korzystać i powiedzieć "coś więcej” o świecie, np. o kulturowych uwarunkowaniach gospodarowania. Zob. np. J. Sójka, Kulturoznawca w świecie gospodarki, „Kultura Współczesna” 2008, nr 1, s. 5 (jest to wstęp do numeru kwartalnika w całości poświęconego kulturowym uwarunkowaniom gospodarki). Zob. także idem, Kulturoznawstwo - od znawstwa do dyscypliny naukowej, „Nauka” 2005, nr 4, s. 97.

${ }^{3}$ A. Appadurai, Nowoczesność bez granic. Kulturowe wymiary globalizacji, przeł. Z. Pucek, Universitas, Kraków 2005, s. 26.

${ }^{4}$ G. Hofstede, Cultures and Organizations. Software of the Mind, McGraw-Hill, New York 1997. 
W każdym razie nasze umysły nie są, przynajmniej w całości, zaprogramowane tak samo. Nie wszyscy w takim samym stopniu reprezentujemy to, co zwykło się nazywać kulturą narodową. Jednostka może należeć do kosmopolitycznej grupy (arystokraci, naukowcy, artyści, menedżerowie), która bardziej związana jest ze swoimi odpowiednikami w innych kulturach narodowych aniżeli z własnymi rodakami reprezentującymi jednak inne grupy lub warstwy społeczne. Jeżeli na przykład w zarządzie Nestlé w Vevey zasiada Meksykanin, to niewykluczone, że jego „zaprogramowanie” umysłu będzie bardziej podobne do sposobu myślenia i odczuwania innych menedżerów z wielu różnych krajów niż do tej wersji, którą reprezentuje przeciętny Meksykanin ${ }^{5}$.

\section{KULTURA (POZORNIE) NIEOBECNA}

Na początku XX wieku powstała szkoła naukowej organizacji pracy (scientific management) związana z nazwiskiem Fredericka Taylora, a także Henry'ego Forda jako najbardziej znanego przedsiębiorcy, który wcielił ją w życie. Jak wiadomo, chodziło tutaj o znalezienie najlepszej metody wykonania danej czynności dzięki eliminacji zbędnych ruchów, szkoleniu pracowników oraz uzależnieniu płacy od wydajności. Tayloryzm był swego rodzaju filozofią taśmy produkcyjnej. Zakładał, iż człowiek powinien dostosować się do tempa pracy maszyny, stając się niejako jej częścią. Taylor oraz Ford zakładali, że interes pracodawcy oraz pracownika jest taki sam: każdemu zależy na zwiększaniu zysków czy też zarobków i jeżeli stworzy się taki system organizacji pracy - wszyscy będą usatysfakcjonowani. Jednocześnie ten rodzaj organizacji produkcji oraz "mechanizacji” pracy ludzkiej dawał szansę masom niewykwalifikowanych robotników na szybkie przeszkolenie i dobry zarobek. Cały proces produkcji podzielony został na dużą liczbę prostych czynności, których wykonywanie nie wymagało wielkich umiejętności i pozwalało stać się szybko częścią wielkiej machiny produkcyjnej.

Przemysł motoryzacyjny w Stanach Zjednoczonych przyciągał emigrantów z wielu krajów, głównie europejskich, w większości chłopów, którzy przypływali do Ameryki w poszukiwaniu chleba. Taylorowski system produkcji nie tylko pozwalał na szybkie rekompensowanie braku doświadczenia $\mathrm{w}$ tego typu pracy, ale także niwelował wszelkie różnice kulturowe.

5 O składzie zarządu tej naprawdę wielokulturowej firmy (pomimo jej szwajcarskich korzeni i miejsca rejestracji centrali) pisze Nina Jacob, Intercultural Management, Kogan Page, London 2003, s. 53. 
Ludzie nieznający języka angielskiego, przywykli do pracy na roli i do życia $\mathrm{w}$ ramach wiejskiej wspólnoty, stawali się z dnia na dzień pracownikami przemysłowymi. Taylor uważał, że system ten gwarantuje podstawową sprawiedliwość w miejscu pracy: wszyscy byli równi wobec wymagań produkcji taśmowej, zarówno Irlandczyk mówiący po angielsku i przybyły do Ameryki kilka lat wcześniej, jak i emigrant z Europy Wschodniej, który dopiero zaczynał pracę i uczył się pierwszych słów w nowym dla siebie języ$\mathrm{ku}^{6}$. A zatem celowo - jeśli wolno tak się wyrazić - zawieszano działanie kultury, czyli tego duchowego wyposażenia człowieka, które chcąc nie chcąc przywoził z sobą do Nowego Świata.

W latach dwudziestych XX wieku przemysłowcom coraz częściej doradzali socjolodzy i psycholodzy. W ramach nurtu stosunków współdziałania (human relations), wiązanego z nazwiskiem Eltona Mayo, człowiek wraz ze wszystkimi swoimi potrzebami (nie tylko materialnymi) staje się bardziej widoczny. Słynny eksperyment w Hawthorne Works miał pokazać, że ludzie pracują wydajniej, jeżeli kierownictwo okazuje im swoje zainteresowanie, dowartościowując ich $\mathrm{w}$ ten sposób. Nie są ważne różnice kulturowe, nie mówi się o nich, jednakże pojawia się tu problem, który dzisiaj określany jest jako wpływ kultury organizacyjnej na motywację pracowników. Eltonowi Mayo jako pierwszemu socjologowi przemysłu chodziło o stworzenie takich warunków w miejscu pracy, aby wystąpić mogła tzw. spontaniczna kooperacja, charakterystyczna dla wspólnot wiejskich, przedindustrialnych, aby ludziom chciało się współpracować. A zatem nie tylko organizacja produkcji, lecz także duch współpracy tutaj się liczył, aczkolwiek dochodziło do podobnej niwelacji różnic kulturowych jak w przypadku tayloryzmu.

Obok „eksperymentu w Hawthorne” w literaturze pojawia się pojęcie „efektu Hawthorne" odnoszące się do sytuacji, w której świadomość uczestniczenia $w$ eksperymencie wpływa na jego wyniki. Szczególnie widoczne było to $\mathrm{w}$ odniesieniu do badań nad wydajnością sześciu dziewcząt składających przełączniki (relay assembly room). Działał tu efekt przygarnięcia świeżo przyjętych do pracy emigrantek, którym stworzono specjalne warunki. Krytyka tego eksperymentu obecna jest $\mathrm{w}$ literaturze przedmiotu już od 1958 roku i właściwie do dzisiaj toczą się spory na temat badań z lat dwudziestych i trzydziestych ubiegłego wieku ${ }^{7}$. W pewnym sensie dopuszczono

\footnotetext{
${ }^{6}$ C. Grey, A Very Short, Fairly Interesting and Reasonably Cheap Book about Studying Organizations, Sage, Los Angeles 2009, s. 39.

7 Jako pierwszy pisał o efekcie Hawthorne Henry A. Landsberger, Hawthorne Revisited. Management and the Worker: Its Critics and Developments in Human Relations in Industry, Cornell University, Ithaca 1959; zob. także: S.W. Draper, The Hawthorne, Pygmalion, Placebo and Other Effects of Expectation: Some Notes, Department of Psychology, University of Glasgow,
} 
się tutaj manipulacji, tworząc sytuację, w której kilka pracownic stało się celebrytkami i, bez względu na warunki pracy, bardzo ochoczo wywiązywało się ze swoich obowiązków. Mayo - podobnie jak Taylor - wyróżnił jeden czynnik, który miał decydować o wydajności: każdemu zależy na uznaniu swoich przełożonych i popularności w miejscu pracy. Wprawdzie można tu mówić o budowaniu kultury organizacyjnej, niemniej prawdziwa różnorodność kulturowa ulega stłamszeniu i nie odgrywa większej roli. Właściwie wciąż mamy do czynienia z tayloryzmem, czyli instrumentalnym traktowaniem pracowników, tyle że opartym na manipulacji psychologicznej ${ }^{8}$.

Koncepcja stosunków współdziałania (human relations) to dopiero początek behawioralnego nurtu w zarządzaniu, który stworzył współczesne zarządzanie zasobami ludzkimi. Douglas McGregor i inni twórcy modelu zasobów ludzkich (human resources model) uważali, że stosunki współdziałania w praktyce oznaczają manipulację pracownikiem ${ }^{9}$. Współczesny model zarządzania zasobami ludzkimi stawia na takie ukształtowanie zachęt i bodźców, aby pracownik miał przede wszystkim poczucie, iż to, co robi, ma sens i jest ważne zarówno dla niego samego, jak i dla firmy oraz jej klientów. Powraca zatem problem kultury organizacyjnej, bowiem traktowanie serio własnej pracy i własnej firmy powinno być jedną z wartości obecnych w miejscu pracy i zapewniających poczucie godności pracownika. Prawdziwe odejście od paternalizmu Taylora i Mayo miałoby przynosić dzisiaj tzw. zarządzanie różnorodnością (diversity management). W organizacjach ponadnarodowych skład etniczny i kulturowy pracowników jest bardzo zróżnicowany. Nie chodzi jednak tylko o to, aby "poradzić sobie” z tą różnorodnością, ale przede wszystkim o to, aby ją wykorzystać dla dobra firmy. Różnorodność sprzyjać ma na przykład kreatywności oraz lepszemu rozpoznaniu potrzeb różnych grup klientów w ramach działalności marketingowej ${ }^{10}$.

\section{KULTURA NA PIERWSZYM PLANIE}

Rok 1982 był przełomowy, jeśli chodzi o obecność problematyki kultury w naukach o zarządzaniu. Tom Peters i Robert Waterman opublikowali książkę, która miała stać się światowym bestsellerem. Zgodnie z jej tytułem -

http://www.psy.gla.ac.uk/ steve/hawth.html [dostęp: 20.08.2014]. Współczesny przykład podaje Hofstede, Cultures and Organizations..., s. 187.

${ }^{8}$ C. Grey, op. cit., s. 47.

9 J.A.F. Stoner, R.E. Freeman, D.R. Gilbert Jr., Kierowanie, przeł. A. Ehrlich, PWE, Warszawa 1997, s. 430 .

10 Ibidem, s. 206. 
In Search of Excellence - autorzy starali się przedstawić najlepsze, ich zdaniem, firmy amerykańskie i wyjaśnić przyczyny ich sukcesów. Pisali: „Bez wyjątku, dominacja i spójność kultury okazała się istotną wartością znakomitych firm. Ponadto im silniejsza kultura i im bardziej zorientowana na rynek, tym mniej potrzeba było dokumentów strategicznych, organizacyjnych schematów czy drobiazgowych procedur i reguł. W tych firmach ludzie od góry do dołu wiedzieli, czego się od nich oczekuje w większości sytuacji, bowiem mała liczba najważniejszych zasad była dla nich absolutnie jasna"11. Nie ma w tej chwili znaczenia, że większość tych firm po latach, jak się okazało, nie zasługiwała na miano doskonałej. Ważne jest natomiast to, iż kultura organizacyjna stała się jednym z głównych tematów opracowań z zakresu teorii zarządzania, a jej badanie na stałe weszło do oferty firm konsultingowych ${ }^{12}$.

Wprawdzie o kulturze organizacyjnej pisano już w latach sześćdziesiątych ubiegłego wieku, ale wówczas, przynajmniej w angielskojęzycznej literaturze, termin ten oznaczał po prostu "klimat" panujący w danej firmie ${ }^{13}$. Dopiero za sprawą Petersa i Watermana stał się narzędziem analitycznym, dzięki któremu można było wytłumaczyć zarówno sukcesy, jak i porażki w zasadzie wszystkich organizacji, od firm produkcyjnych, poprzez administrację państwową, aż po uniwersytety i inne szkoły wyższe. Wprawdzie początkowo nie do końca było wiadomo - jak twierdzi Hofstede - czym dokładnie jest kultura organizacyjna, ale większość badaczy zgadzała się, że chodzi o coś:

- całościowego i systemowego (o całość, która jest czymś więcej niż tylko sumą swoich części),

- historycznie ukształtowanego - poprzez przeszłość organizacji, zwłaszcza jej początki i, bardzo często, osobowość jej założyciela,

- opartego na rytuałach i symbolach, które zazwyczaj studiują antropolodzy,

- konstruowanego społecznie - poprzez grupę ludzi tworzącą organizację,

- „miękkiego” (soft) - chociaż Peters i Waterman twierdzili, że „miękkie jest twarde", a zatem

- trudnego do zmiany - aczkolwiek stopień trudności trudno określić ${ }^{14}$.

11 T.J. Peters, R.H. Waterman Jr., In Search of Excellence. Lessons from America's Best-run Companies, Harper \& Row Publishers, New York 1982, s. 75-76.

12 Zob. np. K.S. Cameron, R.E. Quinn, Diagnosing and Changing Organizational Culture. Based on the Competing Values Framework, Jossey-Bass, San Francisco 2011.

${ }_{13} \mathrm{G}$. Hofstede, Cultures and organizations..., s. 179.

14 Ibidem, s. 179-180. 
Ukazanie się książki In Search of Excellence było wydarzeniem przełomowym z jeszcze jednego powodu. W latach siedemdziesiątych XX wieku amerykańska gospodarka odczuwała dotkliwie zagrożenie ze strony japońskiej konkurencji na wielu rynkach. Koledzy Petersa i Watermana z firmy McKinsey w tym samym roku (1982) opublikowali raport, z którego wynikało, że amerykańskie firmy $\mathrm{w}$ odpowiedzi na to zagrożenie powinny opanować „sztukę japońskiego zarządzania"15. Zamiast racjonalnego podejścia opartego na analizach struktur i strategii, powinny skierować się $\mathrm{w}$ inną stronę. Naśladując japońskich menedżerów i przedsiębiorców, powinny zwracać większą uwagę na miękkie i irracjonalne czynniki, takie jak np. wspólne wartości. Rzeczywiście podzielane przez wszystkich wartości sprawiają, iż pracownicy oddani są wspólnej sprawie, a korzysta na tym jakość produktu lub usługi, co można stwierdzić empirycznie, badając związek kultury organizacyjnej z wydajnością pracy i rentownością firmy.

W ten oto sposób kultura stała się kluczowym pojęciem w teorii zarządzania na przynajmniej dwadzieścia lat, jak uważa Grey ${ }^{16}$. Wprawdzie autorzy bestselleru o doskonałych firmach bardzo się mylili $\mathrm{w}$ odniesieniu do większości przedsiębiorstw, o których pisali, bowiem ich przykładowe firmy po roku miały się już znacznie gorzej (np. IBM) lub nawet całkowicie zniknęły - niemniej kult kultury organizacyjnej pozostał. W szczególności wśród konsultantów i innych specjalistów od wspólnych wartości. Proponują oni listy podstawowych wartości (core values) na małych karteczkach (wersja kieszonkowa), firmowe pieśni lub hymny, wspólne ćwiczenia, parady, zawody sportowe, w sumie wiele najprzeróżniejszych metod integrowania pracowników pod hasłem „nasza firma jest najlepsza”17. Oczywiście, do dzisiaj prowadzi się sporo poważnych badań nad kulturą organizacyjną, które rzeczywiście wnoszą wiele do ogólnej wiedzy na temat organizacji, ale także potrafią "prześwietlić” ukryte mechanizmy funkcjonowania konkretnych firm lub organizacji non-profit ${ }^{18}$. Twierdzi się też, że całe branże mogą mieć własne odrębne kultury, na co zwracano uwage przy okazji niedawnego globalnego kryzysu finansowego. Sektor bankowy, pomimo silnej konkurencji pomiędzy bankami, rządził się podobnymi regułami i odznaczał się swego rodzaju solidarnością zawodową (nie zawsze właściwie rozumianą,

15 R. Pascale, A. Athos, The Art of Japanese Management, Penguin, London 1982. Na rolę tych autorów wskazuje C. Grey, op. cit., s. 65.

${ }^{16}$ C. Grey, op. cit., s. 68.

17 Ibidem, s. 69.

18 Zob. np. Kultura organizacji. Badania etnograficzne polskich firm, red. M. Kostera, GWP, Gdańsk 2007. 
niestety). Tak więc można nie tylko mówić o kulturze Wall Street, lecz również ją badać, co pokazują analizy Karen Ho opublikowane w pracy Zlikwidowani. Etnograficzna analiza Wall Street (2009) ${ }^{19}$.

\section{KULTURA AŻ NADTO OBECNA}

Od lat osiemdziesiątych rozwija się nurt badań nad kulturą gospodarczą symbolizowany przez nazwisko Geerta Hofstedego. Chodzi o praktykę i teorie rozwijane $\mathrm{w}$ ramach tzw. zarządzania międzykulturowego. Wspomniany autor prowadził prace badawcze $\mathrm{w}$ bodaj pięćdziesięciu filiach IBM na całym świecie i doszedł do wniosku, że menedżerowie wielonarodowych firm muszą dostosować styl zarządzania do lokalnych kultur, które ukształtowały ich pracowników ${ }^{20}$. I tak menedżerowie IBM w Meksyku muszą być bardziej autorytarni, podczas gdy ich odpowiednicy w Szwecji - bardziej demokratyczni. Oczywiście, nie sposób zupełnie dostosowywać się do lokalnych zwyczajów, bowiem firma, otwierając filię w odległym od centrali państwie, musi zachować swoją tożsamość, podstawowe elementy kultury organizacyjnej oraz na przykład troskę o jakość produktu czy ochronę środowiska. A zatem chodzi o jednoczesne przystosowanie się i o szkolenie pracowników tak, aby mogli sprostać wymaganiom centrali. Problemem do rozwiązania jest jednak sposób szkolenia oraz dobór osób, które wezmą na siebie ten trud. Czy będą to menedżerowie z centrali wysłani do danego kraju czy też lokalni menedżerowie przeszkoleni w kraju, w którym mieści się centrala? W przypadku firmy BMW funkcjonującej w Tajlandii zdecydowano się na menedżerów lokalnych, którzy dobrze rozumieją mentalność pracowników i potrafią się z nimi porozumieć - oczywiście, w celu przekazania im podstawowych wartości i sposobów działania wypracowanych w centrali21.

W refleksji nad zarządzaniem międzykulturowym dominuje przekonanie o konieczności treningu międzykulturowego opartego na założeniu, że można ludzi uczyć, w jaki sposób komunikować się z przedstawicielami innych kultur. Pracownicy, którzy mają być oddelegowani do pracy w odległych kulturowo obszarach globu, muszą być, rzecz jasna, zaznajomieni z obowiązującymi tam regułami kulturowymi. Rzadziej jednak uwzględnia

${ }^{19}$ Zob. Wywiad z Karen Ho, autorką Liquidated. An Etnography of Wall Street (A. Kaniewska), Antropolog na Wall Street, Instytut Obywatelski, www.instytutobywatelski.pl [dostęp: 12.12.2013].

${ }^{20}$ G. Hofstede, Culture's Consequences. International Differences in Work-related Value, Sage Publications, Beverly Hills 1980, s. 5.

${ }^{21}$ N. Jacob, op. cit., s. 120-121. 
się fakt, iż kultury zmieniają się (również za sprawą kontaktów międzykulturowych) i to, czego uczymy się dzisiaj - jutro może już nie wystarczać. Globalizacja to nie tylko szansa dla mnie na poznanie innych kultur, ale także szansa innych kultur na przyspieszoną ewolucję (aczkolwiek niekoniecznie w dobrym kierunku, czego przykładem może być łatwe opanowywanie świata przez konsumpcyjny styl życia). Oznacza to też szansę dla przedstawicieli innych kultur na względne wyemancypowanie się z własnej kultury. Stąd też ważnym zaleceniem $\mathrm{w}$ treningach międzykulturowych byłoby to, aby w stu procentach poznawać obce kultury, ale jednocześnie nigdy nie traktować ich przedstawicieli jako stuprocentowych reprezentantów tych kultur. Należy bowiem pogodzić założenie, że kultury są względnie stabilnymi całościami, z poglądem, iż jednocześnie zmieniają się i mogą być zmienianie za sprawą międzykulturowych interakcji oraz ukierunkowanego na zmianę treningu międzykulturowego ${ }^{22}$.

Zarządzanie międzykulturowe jest dzisiaj bardzo obszerną dziedziną o niezwykle bogatej literaturze przedmiotu. Trudno byłoby omawiać w tym tekście wszystkie istotne dla tego nurtu zagadnienia. Warto natomiast zwrócić uwagę na to, że zbyt często mówi się o kulturach, rozumiejąc je jako izolowane wyspy, a różnice $\mathrm{z}$ tego wynikające - jako nieprzezwyciężalne. W naukach o zarządzaniu tradycyjnie już przedsiębiorstwo pojmowane jest jako monokulturowa całość23. Tak naprawdę jednak, jak podkreśla A. Koźmiński, „wszystkie organizacje są w mniejszym lub większym stopniu wielokulturowe"24. Podobnie jest z samymi kulturami, które nie mogą być już traktowane jako izolowane całości. Potrzeba zatem większej wrażliwości na istnienie możliwości zmiany kulturowej, która w pewnych okresach może zasadniczo przyspieszać dzięki mediom, handlowi, turystyce, wymianie studentów itp.

Geerta Hofstedego krytykowano za powielanie stereotypów, przedstawianie kultur w formie karykatur (nadmiernie schematycznie), zbytnie przywiązanie do pojęcia kultury narodowej. Tymczasem $w$ ramach jednej kultury możemy odnaleźć wiele jej wariantów, a te same elementy mogą występować $w$ wielu różnych kulturach. Paradoksalnie więc bardzo wiele korzyści można czerpać nie tylko z lektury Hofstedego, ale także z krytyki pod jego adresem oraz wprowadzanych korekt, zwłaszcza przez Fonsa

${ }^{22}$ G. Fink, Cross-cultural Competence and Management - Setting the Stage, „European Journal of Cross-Cultural Competence and Management" 2009, no. 1, s. 43.

23 D. Latusek, Zarządzanie międzykulturowe w Polsce, [w:] Pomiędzy kulturami. Szkice z komunikacji międzykulturowej, red. M. Ratajczak, Wydawnictwo Uniwersytetu Wrocławskiego, Wrocław 2006, s. 134.

24 A.K. Koźmiński, Zarządzanie w warunkach niepewności. Podręcznik dla zaawansowanych, Wydawnictwo Naukowe PWN, Warszawa 2004, s. 182; cyt. za: D. Latusek, op. cit., s. 134. 
Trompenaarsa ${ }^{25}$. Z kolei niemiecki filozof Wolfgang Welsch dopominał się o uznanie zjawiska "transkulturowości”, czyli przenikania się kultur, które dzięki temu zmieniają się wolniej lub szybciej. „Interkulturowość” wciąż zawiera w sobie założenie, że należy godzić z sobą zupełnie odrębne jakości. Tymczasem $\mathrm{w}$ rzeczywistości dominuje przenikanie się kultur - i to warto widzieć, aby nie tworzyć sztucznych problemów ${ }^{26}$.

\section{ZAMIAST KONKLUZJI}

Dużo zatem mówi się o kulturze, międzykulturowości, kompetencjach interkulturowych, transkulturowości i wielu podobnych zagadnieniach. Czasami można odnieść wrażenie, że zbyt wiele, że w dobie globalizacji każdy menedżer wyższego szczebla miałby przypominać kulturoznawcę. Nie zmienia to faktu, iż tak naprawdę zarządzanie międzykulturowe jest po prostu zarządzaniem. Jednocześnie zarządzanie nigdy nie było monokulturowe (tak jak przedsiębiorstwo, o którym pisał A. Koźmiński), nawet jeśli starało się to ukryć. Celem fordyzmu (tayloryzmu) było zduszenie różnic międzykulturowych, ale to właśnie świadczyło o wpływie kultury na stosunki pracy oraz zarządzanie. Dzisiaj, gdy mówimy tyle o kulturze, podejrzewać można, iż tak naprawdę chodzi o wydajność i racjonalizację kosztów tyle że w świecie, który jest inny niż za czasów Taylora. Tak czy owak nie zrozumiemy zarządzania $\mathrm{w}$ zglobalizowanym świecie bez uwzględnienia faktu istnienia wielu kultur i ich wzajemnego przenikania się.

\section{BIBLIOGRAFIA}

Appadurai A., Nowoczesność bez granic. Kulturowe wymiary globalizacji, przeł. Z. Pucek, Universitas, Kraków 2005.

Cameron K.S., Quinn R.E., Diagnosing and Changing Organizational Culture. Based on the Competing Values Framework, Jossey-Bass, San Francisco 2011.

Draper S.W., The Hawthorne, Pygmalion, Placebo and Other Effects of Expectation: Some Notes, Department of Psychology, University of Glasgow, http://www.psy.gla.ac.uk/ steve/hawth.html [dostęp: 20.08.2014].

Fink G., Cross-cultural Competence and Management - Setting the Stage, „European Journal of Cross-Cultural Competence and Management" 2009, no. 1.

${ }^{25}$ F. Trompenaars, C. Hampden-Turner, Siedem wymiarów kultury. Znaczenie różnic kulturowych w dziatalności gospodarczej, przeł. B. Nawrot, Oficyna Wydawnicza, Kraków 2002.

${ }^{26}$ W. Welsch, Transculturality - the Puzzling Form of Cultures Today, [w:] Spaces of Culture: City, Nation, World, eds M. Featherstone, S. Lash, Sage, London 1999. 
Friedman B.M., The Moral Consequences of Economic Growth, Alfred A. Knopf, New York 2005.

Grey C., A Very Short, Fairly Interesting and Reasonably Cheap Book about Studying Organizations, Sage, Los Angeles 2009.

Hofstede G., Culture's Consequences. International Differences in Work-related Value, Sage Publications, Beverly Hills 1980.

Hofstede G., Cultures and Organizations. Software of the Mind, McGraw-Hill, New York 1997.

Jacob N., Intercultural Management, Kogan Page, London 2003.

Kaniewska A., Antropolog na Wall Street, Instytut Obywatelski, www.instytutobywatelski.pl [dostęp: 12.12.2013].

Koźmiński A.K., Zarządzanie w warunkach niepewności. Podręcznik dla zaawansowanych, Wydawnictwo Naukowe PWN, Warszawa 2004.

Kultura organizacji. Badania etnograficzne polskich firm, red. M. Kostera, GWP, Gdańsk 2007.

Landsberger H.A., Hawthorne Revisited. Management and the Worker: Its Critics and Developments in Human Relations in Industry, Cornell University, Ithaca 1959.

Latusek D., Zarządzanie międzykulturowe w Polsce, [w:] Pomiędzy kulturami. Szkice z komunikacji międzykulturowej, red. M. Ratajczak, Wydawnictwo Uniwersytetu Wrocławskiego, Wrocław 2006.

Pascale R., Athos A., The Art of Japanese Management, Penguin, London 1982.

Peters T.J., Waterman R.H. Jr., In Search of Excellence. Lessons from America's Best-run Companies, Harper \& Row Publishers, New York 1982.

Sójka J., Kulturoznawca w świecie gospodarki, „Kultura Współczesna” 2008, nr 1.

Sójka J., Kulturoznawstwo - od znawstwa do dyscypliny naukowej, „Nauka” 2005, nr 4.

Stoner J.A.F., Freeman R.E., Gilbert D.R. Jr., Kierowanie, przeł. A. Ehrlich, PWE, Warszawa 1997.

Trompenaars F., Hampden-Turner Ch., Siedem wymiarów kultury. Znaczenie różnic kulturowych w działalności gospodarczej, przeł. B. Nawrot, Oficyna Wydawnicza, Kraków 2002.

Welsch W., Transculturality - the Puzzling Form of Cultures Today, [w:] Spaces of Culture: City, Nation, World, eds M. Featherstone, S. Lash, Sage, London 1999. 